\title{
Anti-phospholipase A2 receptor antibodies: Current applications in primary membranous nephropathy
}

\author{
Miguel Relvas ${ }^{1,2}$, Rodrigo Batata ${ }^{3}$, Ana Teresa Nunes ${ }^{1,2}$, Luís Coentrão ${ }^{1,2,3}$ \\ ${ }^{1}$ Nephrology Department, Centro Hospitalar e Universitário de São João, Oporto, Portugal \\ ${ }^{2}$ Nephrology \& Infectious Diseases R\&D, i3S - Instituto de Investigação e Inovação em Saúde da Universidade do Porto, Oporto, Portugal \\ ${ }^{3}$ Faculty of Medicine, University of Oporto, Oporto, Portugal
}

\section{ABSTRACT}

Background: Membranous nephropathy ( $M N)$ is among the most common causes of nephrotic syndrome in nondiabetic adults. The podocytic M-type phospholipase A2 receptor (PLA2R) has been identified as the major antigenic target of the immune response that underlies primary membranous nephropathy (PMN). In the last decade, anti-PLA2R antibodies have been seen as promising diagnostic biomarkers for PMN. Other potential uses include assessment of disease activity and prognosis, therapeutic monitoring and prediction of disease recurrence after renal transplant. Objective: To review clinical studies exploring the current role of anti-PLA2R antibodies. Methods: This systematic review was conducted according to PRISMA guidelines. Two databases were searched for articles published between January 2010 and August 2019. Fifty-one studies met the inclusion criteria. Results: Anti-PLA2R antibodies constitute highly sensitive and specific markers for PMN. Antibody titers correlate positively with disease activity. Low levels or seronegativity correlate to higher remission rates. Relative reduction of antibody titers seems to correlate with the likelihood of response to therapy. The value of this antibody in the prediction of post-transplant recurrence is uncertain, as is its use in the pediatric population. Conclusion: Anti-PLA2R antibodies are assuming an increasingly important role in MN management. Anti-PLA2R positivity in the context of nephrotic syndrome is very suggestive of PMN diagnosis. Nevertheless, further efforts are required to define optimal cut-off values for seropositivity and risk stratification.

Keywords: Anti-PLA2R; Biomarkers; Membranous nephropathy.

\section{INTRODUCTION}

Membranous nephropathy ( $\mathrm{MN}$ ) is the denomination of a specific glomerular disease induced by the deposition of immune complexes at the glomerular basement membrane (GBM), causing its thickening. ${ }^{1}$ This immunological process alters the permeability of the glomerular vasculature and is the most common etiology of nephrotic syndrome (NS) in Caucasian adults. ${ }^{2}$

MN's long-term outcomes have been said to follow the "rule of thirds". According to this model, one third of diagnosed patients evolve towards spontaneous remission, one third maintain persistent proteinuria, while another third develop end-stage renal failure in ten years. ${ }^{3}$ Currently, this depiction is considered excessively simplistic and most clinicians opt for a risk-stratification approach when predicting a patient's prognosis and determining the optimal treatment strategy. ${ }^{4}$

MN is classically divided into two subgroups: primary MN (PMN) and secondary MN (SMN). SMN constitutes around $20 \%$ of all MN cases and occurs in the context of underlying conditions (malignancies, drugs, rheumatological diseases and infections). ${ }^{5}$ PMN refers to the remaining cases with no identifiable underlying cause. The pathological mechanism of PMN still remains to be clarified. ${ }^{6}$

In 1959, W. Heymann developed an experimental model in rats that identified megalin, a podocyte antigen, as the main target for circulating antibodies responsible for the formation of GBM deposits.
Despite the importance of this discovery, the mechanism described wasn't directly transposable to humans. ${ }^{7-11}$

In 2003, P. Ronco observed that pregnant women with neutral endopeptidase (NEP) deficiency developed IgG1 and IgG4 NEP-binding antibodies capable of crossing the placenta, inducing neonatal MN. This confirmed that podocyte antigens constitute potential targets for circulating antibodies that may lead to complement activation and subsequent deposition of glomerular immune complexes. ${ }^{12,13}$

In PMN specifically, M-type phospholipase A2 receptor (PLA2R) has been identified as the main target antigen. Circulating anti-PLA2R antibodies are present in approximately $70 \%$ of PMN patients. ${ }^{14}$ Other antigenic targets include thrombospondin type 1 domain-containing 7A (THSD7A), with anti-THSD7A antibodies present in 3-5\% of PMN patients. ${ }^{15,16}$ Recently, using laser microdissection of glomeruli and mass spectrometry analysis of renal biopsies, Sethi et al. discovered two novel antigens that also play a role in $\mathrm{MN}$ : exostosin (associated with autoimmune disorders) and NELL-1. ${ }^{17-19}$

Recent studies suggest a strong correlation between the levels of circulating anti-PLA2R antibodies and disease activity, typically estimated through proteinuria quantification. Special care is required in the interpretation of discordant antibody and proteinuria levels. Low or absent antibody levels may indicate remission or decreased disease activity, but simultaneously increased proteinuria levels may constitute an indirect sign of glomerular structural changes and tubular damage. ${ }^{20}$ 
Studies also suggest anti-PLA2R quantification may be used to predict disease outcomes and to evaluate patient response to treatment. $^{21,22}$ Other potential applications of this marker include the estimation of the risk of PMN recurrence after kidney transplant and immunosuppressive therapy optimization. ${ }^{23-25}$

In this paper, we analyzed data from recent clinical studies to understand the current role of anti-PLA2R antibodies on several fronts: MN diagnosis, determination of disease activity, therapeutic monitoring, differential diagnosis with secondary forms and evaluation of the risk of disease recurrence.

\section{METHODS}

This systematic review was conducted in accordance with Preferred Reporting Items for Systematic Reviews and Meta-Analyses (PRISMA) guidelines. The article search for the present review was carried out from September 2018 to September 2019.

Two different electronic databases were used, PUBMED and SCOPUS. The authors agreed on a set of inclusion and exclusion criteria for automatic depuration. The search criteria were coded into queries specific to each database with "phospholipase a2" and "membranous nephropathy" as keywords.
The resulting papers had their abstracts screened following predefined criteria to select original articles with well-defined assessment methodology relevant to the scope of this review.

Figure 1 attempts to summarize the article search and depuration protocol for this paper.

The following information - study type, subject number, anti-PLA2R positivity, PLA2R expression, assay used and clinical outcomes - was extracted for each selected paper (when applicable) and are shown on table I. Divergences over inclusion of studies and interpretation of data were resolved by consensus discussion. Due to significant heterogeneity in terms of methodology, participant selection, and reported outcome measures, the results of the included studies were not pooled but instead presented qualitatively.

\section{RESULTS}

In total, 51 articles were critically analyzed. Most of the selected studies were prospective in nature $(n=31,60.8 \%)$. All patients with $\mathrm{MN}$ included in the clinical trials had pathological confirmation of their diagnosis. Anti-PLA2R antibody detection was predominantly performed through conventional enzyme-linked immunosorbent assay (ELISA) and indirect immunofluorescence testing (PLA2R IIFT, Euroimmun).

\section{Figure 1}

Breakdown of obtained manuscripts from the initial search to studies included in the review, including queries used for each database.

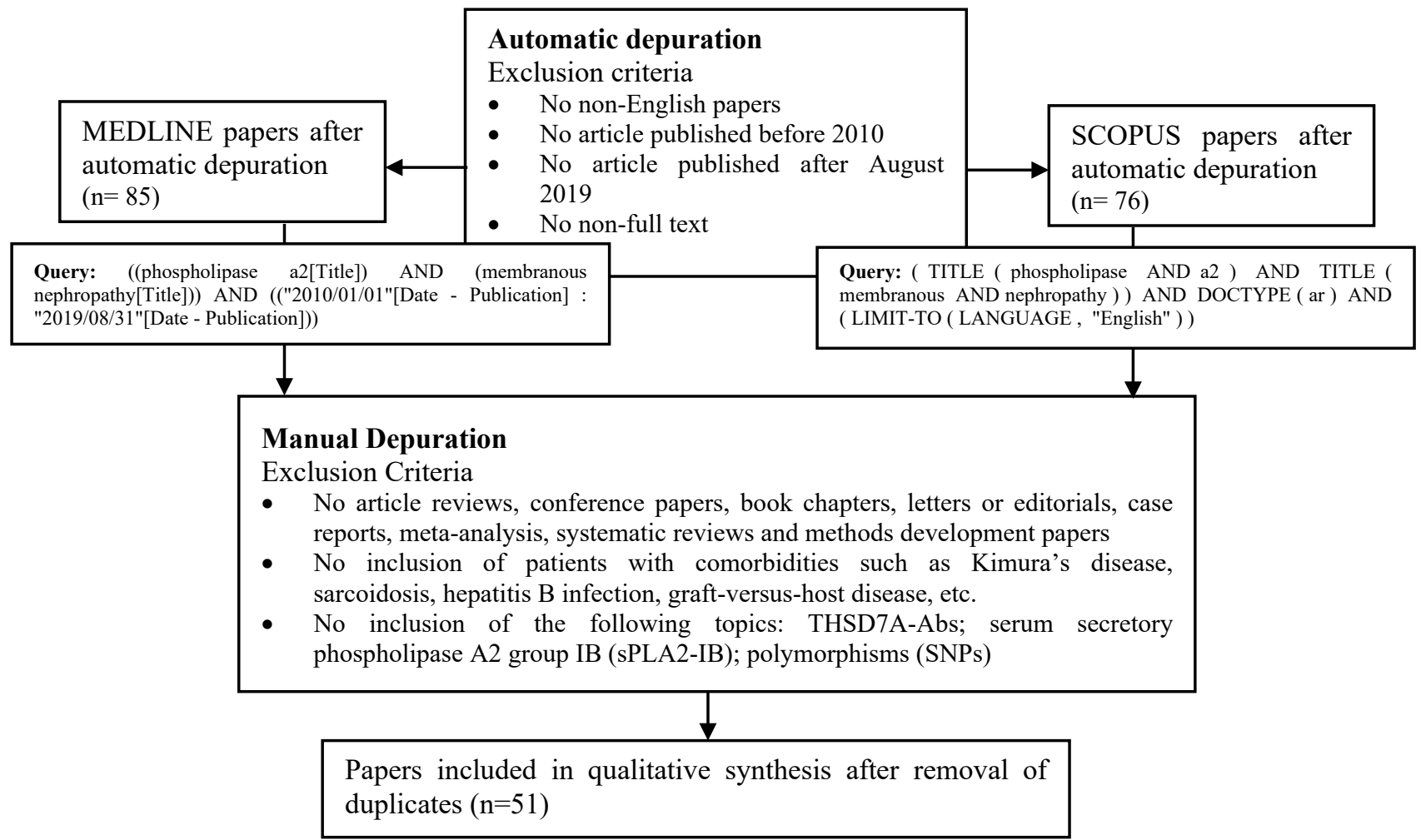


$\underline{\text { Table I }}$

\begin{tabular}{|c|c|c|c|c|c|c|}
\hline Author (year) & Study type & Patients (n) & Anti-PLA2R1+ (n/\%) & $\begin{array}{c}\text { PLA2R } \\
\text { expression \% }\end{array}$ & Assay & Clinical outcome \\
\hline $\begin{array}{l}\text { Hoxha et al., } \\
2014^{47}\end{array}$ & Prospective & $n=133$ & NR & NR & $\begin{array}{l}\text { ELISA } \\
\text { IIFT }\end{array}$ & $\begin{array}{l}81 \% \text { reduction in anti-PLA2R antibody levels paralleled by a } 39 \% \text { reduction } \\
\text { in proteinuria. }\end{array}$ \\
\hline $\begin{array}{l}\text { Hoxha et al., } \\
2014^{43}\end{array}$ & Prospective & $n=118$ & NR & NR & ELISA & $\begin{array}{l}\text { High anti-PLA2R antibody levels are associated with an accelerated loss of } \\
\text { renal function. }\end{array}$ \\
\hline $\begin{array}{l}\text { Hihara et al., } \\
2016^{34}\end{array}$ & Prospective & $\begin{array}{c}n=59 \\
38 \mathrm{PMN} / 21 \mathrm{SMN}\end{array}$ & $\begin{array}{l}19 / 50 \% \text { PMN } \\
0 / 0 \% \text { SMN }\end{array}$ & NR & $\begin{array}{l}\text { ELISA } \\
\text { IIFA }\end{array}$ & $\begin{array}{l}\text { Anti-PLA2R positivity was highly specific of PMN and was associated with } \\
\text { glomerular lgG4-predominant deposition. }\end{array}$ \\
\hline $\begin{array}{l}\text { Qin et al., } \\
2011^{30}\end{array}$ & Prospective & $\begin{array}{c}n=106 \\
60 \text { PMN / } 46 \text { SMN }\end{array}$ & $\begin{array}{l}\text { 49/82\% PMN } \\
5 / 10.9 \% \text { SMN }\end{array}$ & NR & WB & $\begin{array}{l}\text { Detection of anti-PLA2R antibodies is a sensitive test ( } 82 \%) \text { for PMN. Anti- } \\
\text {-PLA2R positivity was largely absent in SMN patients. }\end{array}$ \\
\hline Xu et al., $2017^{55}$ & Retrospective & $n=231$ & NR & $189 / 81.8 \%$ & IIFA & $\begin{array}{l}\text { Non-PLA2R associated PMN responds more quickly to IS therapy. There } \\
\text { were no significant differences in terms of renal function. }\end{array}$ \\
\hline $\begin{array}{l}\text { Ardalan et al., } \\
2013^{68}\end{array}$ & Prospective & $\begin{array}{c}n=30 \\
23 \mathrm{PMN} / 2 \mathrm{SMN}\end{array}$ & $\begin{array}{l}17 / 74 \% \mathrm{PMN} \\
0 / 0 \% \mathrm{SMN}\end{array}$ & NR & IIFA & $\begin{array}{l}\text { No correlation found between anti-PLA2R antibody and proteinuria level. } \\
\text { Proteinuria is not a good marker of disease activity but may reflect the glo- } \\
\text { merular damage. }\end{array}$ \\
\hline $\begin{array}{l}\text { Gupta et al., } \\
2016^{60}\end{array}$ & Retrospective & $n=16$ & NR & NR & ELISA & $\begin{array}{l}\text { Pre-transplant PLA2RAb }>29 \mathrm{RU} / \mathrm{mL} \text { predicts MN recurrence with a sensitiv- } \\
\text { ity of } 85 \% \text { and a specificity of } 92 \% \text {. Patients with recurrent disease despite } \\
\text { undetectable anti-PLA2R antibodies should be studied for occult malignancy } \\
\text { and different antigens. }\end{array}$ \\
\hline $\begin{array}{l}\text { Yang et al., } \\
2016^{35}\end{array}$ & Retrospective & $n=438$ & NR & NR & ELISA & $\begin{array}{l}\text { IgG4 levels have higher predictive accuracy for clinical remission than total } \\
\text { antibodies. }\end{array}$ \\
\hline $\begin{array}{l}\text { Zhang et al., } \\
2017^{28}\end{array}$ & Retrospective & $n=458$ & $\begin{array}{l}1^{\text {st }} \text { cut-off: } 84.06 \% \\
2^{\text {nd }} \text { cut-off: } 71.01 \%\end{array}$ & NR & TRFIA & $\begin{array}{l}\text { Serum anti-PLA2R-IgG levels are significantly higher in PMN patients than in } \\
\text { those with SMN. Renal deterioration is more severe in patients with higher } \\
\text { antibody titers. }\end{array}$ \\
\hline $\begin{array}{l}\text { Kim et. al., } \\
2015^{26}\end{array}$ & Prospective & $\begin{array}{c}n=160 \\
93 \mathrm{PMN} / 14 \mathrm{SMN}\end{array}$ & $41 / 44.1 \%$ & NR & $\begin{array}{l}\text { ELISA } \\
\text { WB }\end{array}$ & $\begin{array}{l}\text { High levels of anti-PLA2R antibodies are correlated with low remission rates } \\
\text { and greater disease severity. ELISA and WB have a concordance rate of } \\
72.1 \% \text {. }\end{array}$ \\
\hline $\begin{array}{l}\text { Hayashi et al., } \\
2015^{58}\end{array}$ & Prospective & $n=25$ & $16 / 73 \%$ & NR & ELISA & $\begin{array}{l}\text { PLA2R-related PMN patients have a lower remission rate and a worse clini- } \\
\text { cal outcome than PLA2R-unrelated PMN patients. IgG4-dominant deposi- } \\
\text { tion greater in PLA2R related PMN. }\end{array}$ \\
\hline $\begin{array}{l}\text { Song et al., } \\
2018^{38}\end{array}$ & Prospective & $n=66$ & NR/52.1\% & NR & ELISA & $\begin{array}{l}\text { Higher spontaneous remission rates in anti-PLA2R-negative patients. Posi- } \\
\text { tive correlation between proteinuria and anti-PLA2R antibody levels. Inci- } \\
\text { dence of stage } 3 \text { and above CKD is higher in anti-PLA2R positive patients. }\end{array}$ \\
\hline $\begin{array}{l}\text { Jullien et al., } \\
2017^{50}\end{array}$ & Retrospective & $n=68$ & NR & NR & ELISA & $\begin{array}{l}\text { Anti-PLA2R antibodies vary in a dose-response manner with remission. Anti- } \\
\text {-PLA2R antibody baseline values are not useful to predict disease activity. }\end{array}$ \\
\hline $\begin{array}{l}\text { Radice et al. } \\
2018^{31}\end{array}$ & Prospective & $\begin{array}{l}n=479 \\
178 \text { PMN } \\
32 \text { SMN }\end{array}$ & $70.6 \%$ PMN & NR & IIFA & $\begin{array}{l}\text { Anti-PLA2R positivity in a MN patient is not sufficient to exclude a second- } \\
\text { ary cause, particularly in patients considered at risk for malignancies. }\end{array}$ \\
\hline $\begin{array}{l}\text { Jatem Escalante } \\
\text { et al., } 2015^{49}\end{array}$ & Retrospective & $n=55$ & NR & NR & ELISA & $\begin{array}{l}\text { Anti-PLA2R antibody negativity is associated with higher likelihood of spon- } \\
\text { taneous remission. }\end{array}$ \\
\hline Liu et al., $2018^{27}$ & Prospective & $\begin{array}{c}n=39 \\
27 \text { PMN } \\
5 \text { SMN }\end{array}$ & $\begin{array}{l}24 / 88.9 \% \text { PMN } \\
2 / 40 \% \text { SMN }\end{array}$ & NR & ELISA & $\begin{array}{l}\text { Serum anti-PLA2R antibody and PLA2R expression in kidney tissue had an } \\
100 \% \text { concordance rate. }\end{array}$ \\
\hline $\begin{array}{l}\text { Akiyama et al., } \\
2015^{48}\end{array}$ & Retrospective & $\begin{array}{c}n=131 \\
100 \text { PMN } \\
31 \text { SMN }\end{array}$ & $\begin{array}{l}53 / 53 \% \text { PMN } \\
0 / 0 \% \text { SMN }\end{array}$ & NR & WB & $\begin{array}{l}\text { The prevalence of anti-PLA2Rabs is higher in patients with NS when com- } \\
\text { pared to patients without this condition. Positivity of anti-PLA2R is correlat- } \\
\text { ed with a greater number of patients with serum albumin } \leq 3 \mathrm{~g} / \mathrm{dL} \text {. }\end{array}$ \\
\hline $\begin{array}{l}\text { Hoxha et al., } \\
2015^{36}\end{array}$ & Prospective & $n=37$ & NR & NR & IIFA & $\begin{array}{l}\text { The use of IS does not alter the probability of achieving remission in sero- } \\
\text { negative PMN patients. }\end{array}$ \\
\hline $\begin{array}{l}\text { Qin et al., } \\
2016^{46}\end{array}$ & Retrospective & $n=572$ & $392 / 68.5 \%$ & $519 / 90 \%$ & $\begin{array}{l}\text { ELISA } \\
\text { IF }\end{array}$ & $\begin{array}{l}\text { Patients who have dual positivity for anti-PLA2R antibodies and PLA2R glo- } \\
\text { merular antigen have higher levels of proteinuria and lower probability of } \\
\text { achieving remission. Disease relapse was more frequent patients with high- } \\
\text { er levels of PLA2R antigen deposition. }\end{array}$ \\
\hline $\begin{array}{l}\text { Hoxha et al., } \\
2012^{45}\end{array}$ & Prospective & $n=88$ & $60 / 68 \%$ & 61 & IIFA & $\begin{array}{l}\text { No correlation was found between proteinuria and anti-PLA2R levels. A } \\
\text { strong correlation was found between antibody levels and glomerular } \\
\text { expression of PLA2R antigen in PMN patients. }\end{array}$ \\
\hline $\begin{array}{l}\text { Medrano et al., } \\
2015^{53}\end{array}$ & Prospective & $n=79$ & NR & NR & ELISA & $\begin{array}{l}\text { No correlation was found between antibody levels before treatment and } \\
\text { clinical outcome. Relative antibody titer reduction has a superior predictive } \\
\text { value than absolute values at 3- and 6-months post-treatment. }\end{array}$ \\
\hline
\end{tabular}




\begin{tabular}{|c|c|c|c|c|c|c|}
\hline Author (year) & Study type & Patients (n) & Anti-PLA2R1+ (n/\%) & \begin{tabular}{c|} 
PLA2R \\
expression \%
\end{tabular} & Assay & Clinical outcome \\
\hline $\begin{array}{l}\text { Dou et al., } \\
2016^{32}\end{array}$ & Prospective & $n=229$ & $\begin{array}{l}1^{\text {st }} \text { cut-off: } 65.3 \% \\
2^{\text {nd }} \text { cut-off: } 60.2 \% \\
3^{\text {rd }} \text { cut-off: } 45.8 \%\end{array}$ & NR & ELISA & A cutoff of $14 \mathrm{RU} / \mathrm{ml}$ should be used to diagnose PMN. \\
\hline $\begin{array}{l}\text { Ruggenenti et } \\
\text { al., } 2015^{51}\end{array}$ & Prospective & $n=132$ & NR & NR & ELISA & $\begin{array}{l}\text { Anti-PLA2R antibody depletion preceded complete remission. Low anti-PLA2R } \\
\text { titer at baseline and full antibody depletion } 6 \text { months post-rituximab predict- } \\
\text { ed remission. Disease relapse was predicted by resurgence of antibodies. }\end{array}$ \\
\hline $\begin{array}{l}\text { Kumar et al., } \\
2015^{62}\end{array}$ & Prospective & $n=5$ & $3 / 60 \%$ & $100 \%$ & ELISA & $\begin{array}{l}\text { There seems to be a role for PLA2R in the pathogenesis of pediatric PMN, } \\
\text { but more studies with larger samples are needed. }\end{array}$ \\
\hline $\begin{array}{l}\text { Seitz el al., } \\
2014^{59}\end{array}$ & Retrospective & $\mathrm{n}=15$ & NR & NR & ELISA & $\begin{array}{l}\text { IgG4 anti-PLA2R positivity at the time of transplant doesn't predict recur- } \\
\text { rence. Positivity for IgG4 anti-PLA2R during follow-up (after } 6 \text { months) is a } \\
\text { risk factor for recurrence. IgG4 anti-PLA2R titers may help predict disease } \\
\text { relapse. }\end{array}$ \\
\hline $\begin{array}{l}\text { Roy et al., } \\
2017^{56}\end{array}$ & Retrospective & $n=190$ & $70.2 \%$ & NR & $\mathrm{IHC}$ & $\begin{array}{l}\text { Anti-PLA2R IHC is a specific marker for differential diagnosis between PMN } \\
\text { and SMN. }\end{array}$ \\
\hline $\begin{array}{l}\text { Seitz-Polski et } \\
\text { al., } 2018^{67}\end{array}$ & Prospective & $n=58$ & NR & NR & ELISA & Epitope spreading is an independent negative predictor of remission. \\
\hline $\begin{array}{l}\text { Wang et al. } \\
2016^{37}\end{array}$ & Retrospective & $\mathrm{n}=131$ & NR & NR & $\begin{array}{l}\text { ELISA } \\
\text { IIFA }\end{array}$ & $\begin{array}{l}\text { There is a correlation between seronegativity and remission. High titers cor- } \\
\text { relate to greater disease activity. Dual negativity for anti-PLA2R antibodies } \\
\text { and glomerular PLA2R deposits suggest SMN. }\end{array}$ \\
\hline $\begin{array}{l}\text { Yachha et al., } \\
2018^{44}\end{array}$ & Prospective & $n=63$ & $\begin{array}{l}\mathrm{NR} / 55.2 \% \mathrm{PMN} \\
0 / 0 \% \mathrm{SMN}\end{array}$ & NR & ELISA & $\begin{array}{l}\text { There appears to be a direct correlation between antibody titers and dis- } \\
\text { ease activity. Seropositive patients presented worse results in terms of } \\
\text { hypoalbuminemia and proteinuria. }\end{array}$ \\
\hline $\begin{array}{l}\text { Segarra- } \\
\text {-Medrano et al. } \\
2014^{69}\end{array}$ & Prospective & $\begin{array}{l}n=64 \\
47 \mathrm{PMN} \\
17 \mathrm{SMN}\end{array}$ & $\begin{array}{l}\text { IIFA }-72.3 \% \text { PMN } \\
\text { ELISA }-74.5 \% \text { PMN }\end{array}$ & $76.6 \%$ & $\begin{array}{l}\text { IIFA } \\
\text { ELISA } \\
\text { IHC }\end{array}$ & $\begin{array}{l}\text { No correlation was found between anti-PLA2R titers and proteinuria or } \\
\text { albuminemia. IIFA and ELISA have high concordance rates and specificity. } \\
\text { Seropositive patients with anti-PLA2R deposits have present with more sig- } \\
\text { nificant proteinuria. }\end{array}$ \\
\hline Liu et al., $2016^{65}$ & Prospective & $n=252$ & NR & $\begin{array}{l}82 \% \text { PMN } \\
16.7 \% \text { SMN }\end{array}$ & IIFA & $\begin{array}{l}\text { Dual positivity can be useful to distinguish PMN from SMN. PMN patients } \\
\text { with positivity for glomerular PLA2R deposits present superior response to IS. }\end{array}$ \\
\hline Oh et al., $2013^{39}$ & Prospective & $n=100$ & $69 / 69 \%$ & NR & WB & $\begin{array}{l}\text { Anti-PLA2R antibody levels correlate directly to proteinuria and hypoalbu- } \\
\text { minemia. No correlation was found between anti-PLA2R antibody levels and } \\
\text { remission. }\end{array}$ \\
\hline $\begin{array}{l}\text { Debiec et al., } \\
2011^{23}\end{array}$ & Retrospective & $n=19$ & NR & NR & $\begin{array}{l}\text { IIFA } \\
\text { WB }\end{array}$ & $\begin{array}{l}\text { No correlation was found between anti-PLA2R antibody levels at the time of } \\
\text { transplantation and disease recurrence. }\end{array}$ \\
\hline Lin et al., $2015^{29}$ & Retrospective & $n=279$ & NR/60\% & NR & ELISA & $\begin{array}{l}\text { Anti-PLA2R antibody levels correlate to proteinuria and hypoalbuminemia. } \\
\text { Good diagnostic accuracy for PMN. }\end{array}$ \\
\hline $\begin{array}{l}\text { Gopalakrishnan } \\
\text { et al., } 2016^{40}\end{array}$ & Prospective & $\begin{array}{l}n=75 \\
60 \text { PMN } \\
15 \text { SMN }\end{array}$ & $45 / 75 \%$ & NR & IIFA & Anti-PLA2R antibody levels correlate to proteinuria and hypoalbuminemia. \\
\hline $\begin{array}{l}\text { Kimura et al., } \\
2017^{70}\end{array}$ & Retrospective & $n=169$ & $\begin{array}{l}\text { NR/48\% PMN } \\
\text { NR/0\% SMN }\end{array}$ & NR & IIFA & $\begin{array}{l}\text { Alfa enolase autoantibody may facilitate the access of other antibodies to } \\
\text { the podocyte (ex. anti-PLA2R). }\end{array}$ \\
\hline $\begin{array}{l}\text { Kanda et al., } \\
2017^{61}\end{array}$ & Retrospective & $n=34$ & NR & $6 \%$ & $\operatorname{SIM}$ & $\begin{array}{l}\text { The two patients with PLA2R positivity were over } 10 \text { years of age. } \\
\text { Granular glomerular staining is weaker when compared to PMN adult } \\
\text { patients. These findings suggest PLA2R has a limited role in pediatric PMN, } \\
\text { particularly in preteen patients. }\end{array}$ \\
\hline $\begin{array}{l}\text { Wu et al., } \\
2017^{41}\end{array}$ & Retrospective & $n=73$ & $\begin{array}{l}\text { NR/85.4\% PMN } \\
\text { NR/29.4\% SMN }\end{array}$ & $\begin{array}{l}91.7 \% \mathrm{PMN} \\
29.4 \% \mathrm{SMN}\end{array}$ & IIFA & $\begin{array}{l}\text { Anti-PLA2R antibody levels and glomerular PLA2R deposits correlate to pro- } \\
\text { teinuria and hypoalbuminemia (disease activity). }\end{array}$ \\
\hline $\begin{array}{l}\text { Yeo et al., } \\
2018^{64}\end{array}$ & Retrospective & $n=115$ & NR & $83 \%$ & $\mathrm{IHC}$ & $\begin{array}{l}\text { PLA2R and IgG4 bipositivity showed a specificity of } 96.4 \% \text { for PMN. This detec- } \\
\text { tion method can be useful to differentiate primary and second forms of MN. }\end{array}$ \\
\hline $\begin{array}{l}\text { Radice et al., } \\
2016^{42}\end{array}$ & Prospective & $n=42$ & NR & NR & IIFA & $\begin{array}{l}\text { Anti-PLA2R antibody levels correlate to proteinuria and hypoalbuminemia. } \\
\text { The probability of proteinuria remission increased } 6.5 \text { times after seronega- } \\
\text { tivation. Evaluation of anti-PLA2R may be useful for optimizing IS. }\end{array}$ \\
\hline $\begin{array}{l}\text { Segarra- } \\
\text {-Medrano et al., } \\
2014^{54}\end{array}$ & Prospective & $\mathrm{n}=36$ & NR & NR & ELISA & $\begin{array}{l}\text { No correlation was found between antibody levels before treatment and } \\
\text { clinical outcome. Relative reduction of antibodies level was significantly } \\
\text { greater in those who achieved remission. Relative reduction in antibody } \\
\text { titers at } 3 \text { months predicted response at } 6 \text { and } 9 \text { months. Relative titer } \\
\text { reduction at } 6 \text { months predicted response at } 12 \text { months. }\end{array}$ \\
\hline $\begin{array}{l}\text { Kao et al., } 2015 \\
(66)\end{array}$ & Prospective & $n=74$ & NR & NR & NR & $\begin{array}{l}\text { A three-domain complex consisting of cysteine- rich (CIS), fibronectin-like } \\
\text { type II (Fnll) and C-type lectin-like domain } 1 \text { (CTLD1) is likely to be the } \\
\text { immunodominant epitope of PLA2R. }\end{array}$ \\
\hline
\end{tabular}




\begin{tabular}{|c|c|c|c|c|c|c|}
\hline Author (year) & Study type & Patients (n) & Anti-PLA2R1+ (n/\%) & \begin{tabular}{|c|} 
PLA2R \\
expression \%
\end{tabular} & Assay & Clinical outcome \\
\hline $\begin{array}{l}\text { Tampoia et al., } \\
2018^{33}\end{array}$ & Prospective & $n=67$ & NR/ 88.1\% & NR & ELISA & $\begin{array}{l}\text { Anti-PLA2R antibody levels and glomerular PLA2R deposits correlate to pro- } \\
\text { teinuria, hypoalbuminemia and serum creatinine. }\end{array}$ \\
\hline $\begin{array}{l}\text { Zhang et al., } \\
2019 \\
(63)\end{array}$ & Retrospective & $n=225$ & NR & $\begin{array}{l}82.7 \% \mathrm{AP} \\
42.1 \% \mathrm{PP}\end{array}$ & $\mathrm{IHC}$ & $\begin{array}{l}\text { Clinical features and prevalence of PLA2R positive staining in adolescent } \\
\text { patients with PMN was similar to the adult population, suggesting close eti- } \\
\text { ology and pathogenesis. Younger children with PMN were mostly negative } \\
\text { for PLA2R staining, suggesting different underlying etiology. }\end{array}$ \\
\hline $\begin{array}{l}\text { Barrett et al., } \\
2019^{3}\end{array}$ & Prospective & $n=14$ & $14 / 100 \%$ & NR & ELISA & $\begin{array}{l}\text { Belimumab treatment in participants with PMN can reduce anti-PLA2R- } \\
\text {-antibody levels, subsequently reducing proteinuria. }\end{array}$ \\
\hline $\begin{array}{l}\text { Bobart et al., } \\
2018^{15}\end{array}$ & Retrospective & $\begin{array}{l}\mathrm{n}=838 \\
90 \mathrm{PMN}\end{array}$ & $143 / 17.1 \%$ & $96.7 \%$ & $\begin{array}{l}\text { ELISA } \\
\text { SIM }\end{array}$ & $\begin{array}{l}\text { Among patients with preserved kidney function and no evidence of second- } \\
\text { ary causes, a positive PLA2R antibody test is highly predictive of tissue diag- } \\
\text { nosis of PLA2R-associated MN. }\end{array}$ \\
\hline $\begin{array}{l}\text { Cheng et al., } \\
2018^{71}\end{array}$ & Retrospective & $\begin{array}{l}n=259 \\
146 \text { PMN }\end{array}$ & $102 / 69.9 \%$ & NR & ELISA & $\begin{array}{l}\text { Study findings underscore the diagnostic potential of total serum anti-PLA2R } \\
\text { antibodies and highlight the importance of antibody subtype } 4 \text { over other } \\
\text { subtypes. }\end{array}$ \\
\hline Chi et al., $2019^{72}$ & Prospective & $\begin{array}{c}n=79 \\
72 \mathrm{PMN}\end{array}$ & $50 / 69.4 \%$ & NR & $\begin{array}{l}\text { ELISA } \\
\text { IIFA }\end{array}$ & $\begin{array}{l}\text { Indirect evidence of anti-PLA2R antibody as an etiologic factor in PMN } \\
\text { patients. The role of C5a in the disease course and on inflammatory cells is } \\
\text { worth clarifying. }\end{array}$ \\
\hline $\begin{array}{l}\text { Provatopoulou } \\
\text { et al., } 2018^{73}\end{array}$ & Retrospective & $n=33$ & $16 / 48.5 \%$ & NR & ELISA & $\begin{array}{l}\text { Low levels of anti-PLA2R antibodies at diagnosis are predictive of disease } \\
\text { remission following IS. Serial anti-PLA2R measurements correlate with clini- } \\
\text { cal status throughout the follow-up period. }\end{array}$ \\
\hline Qu et al., $2018^{52}$ & Prospective & $n=359$ & $234 / 75.2 \%$ & NR & $\begin{array}{l}\text { ELISA } \\
\text { IIFA }\end{array}$ & $\begin{array}{l}\text { Antibody positivity and antibody titers might predict treatment response } \\
\text { and kidney outcomes in PMN. }\end{array}$ \\
\hline Li et al., $2019^{57}$ & Prospective & $n=51$ & $34 / 66.77 \%$ & $45 / 88.24 \%$ & $\begin{array}{l}\text { ELISA } \\
\text { SIM }\end{array}$ & $\begin{array}{l}\text { Disease status and prognosis correlated more closely with serum Anti- } \\
\text {-PLA2R antibody titers than with the presence of glomerular PLA2R antigen } \\
\text { deposits. Serum positivity was associated with more severe clinical symp- } \\
\text { toms and worse prognosis, which was probably associated with increased } \\
\text { IgG4 deposition. }\end{array}$ \\
\hline $\begin{array}{l}\text { Fervenza et al., } \\
2019^{74}\end{array}$ & Prospective & $n=130$ & $96 / 74 \%$ & NR & ELISA & $\begin{array}{l}\text { Rituximab was noninferior to cyclosporine in inducing complete or partial } \\
\text { remission of proteinuria at } 12 \text { months and superior in maintaining protein- } \\
\text { uria remission up to } 24 \text { months. }\end{array}$ \\
\hline
\end{tabular}

AP - Adult population; CKD - Chronic kidney disease; ELISA - Enzyme-linked immunosorbent assay; EM - Electron microscopy; PMN - Primary membranous nephropathy; IHC - Immunohistochemistry; IIFA - Indirect immunofluorescence assay; IS - Immunosuppression; NR - Not reported; NS - Nephrotic syndrome; PP - Pediatric population; SIM - Standard immunofluorescence microscopy; SMN - Secondary membranous nephropathy; SNP - Single nucleotide polymorphisms; TRFIA - Time-resolved fluoroimmunoassay

\section{Anti-PLA2R antibodies and PMN diagnosis}

The consensus is that anti-PLA2R antibodies constitute highly sensitive and specific biomarkers of PMN in the adult population.

Reported sensitivity varied between 44.1 and $88.9 \% .^{26,27}$ Interstudy variability mainly relates to different cut-off values and quantification methods used. The inclusion of patients already under immunosuppressive treatment may have contributed to the emergence of false negatives. ${ }^{28-34}$

Regarding ELISA testing, commercially available kits have a manufacturer's recommended cut-off value of $14 \mathrm{RU} / \mathrm{mL}$, used by most of the included articles. Tampoia et al. adopted an adapted cut-off value of $2.7 \mathrm{RU} / \mathrm{mL}$ with increased sensitivity $(88,1 \%)$ and no impact on the test's specificity. ${ }^{33}$

\section{Anti-PLA2R titers, disease activity and response to therapy}

Most included studies suggested a linear correlation between antibody titers and PMN activity. 26,33,43-48,35-42
Isolated pre-treatment values appear to be inaccurate predictors of response to treatment. Anti-PLA2R seronegative individuals, however, were found to have higher likelihood of spontaneous remission. ${ }^{20,30,36-38,46,49-52}$ In these cases, Hoxha et al. reported that immunosuppression does not seem to increase the likelihood of remission when compared to supportive therapy. ${ }^{36}$

The rate of anti-PLA2R decline seems to be a superior indicator of response to treatment. Two studies by Medrano et al. showed no association between isolated antibody titers prior and clinical response. In the same trials, the relative reduction of antibodies after initiation of therapy had an apparent correlation with time elapsed until remission and the likelihood of achieving it. ${ }^{53,54}$

\section{Anti-PLA2R antibody titers versus antigen deposits}

Various authors also investigated the role of PLA2R antigen glomerular deposits as biomarkers of $\mathrm{MN}$ - despite reports of higher sensitivity when compared to anti-PLA2R antibodies, PLA2R antigen deposits seem to have a weaker correlation with disease status and prognosis. Dual positivity is correlated with higher disease activity 
and lower remission rates. Dual negativity, on the other hand, is highly suggestive of secondary MN. 27,37,45,46,55-58

\section{Anti-PLA2R antibodies and renal transplantation}

There is no consensus regarding the usefulness of anti-PLA2R baseline quantification when it comes to stratifying the risk of disease recurrence after kidney transplant. Two of the reviewed articles dismiss a correlation between antibody titers at the time of transplantation and risk of disease recurrence..$^{23,59}$ On the other hand, Gutpta et al.'s results suggest pre-transplant titers above $29 \mathrm{RU} / \mathrm{mL}$ are predictive of disease recurrence with high sensitivity $(85 \%)$ and specificity (92\%). ${ }^{60}$ Seitz-Polski et al. suggest that positive IgG4 anti-PLA2R activity during follow-up is a significant risk factor for MN relapse. ${ }^{59}$

\section{PLA2R studies in the pediatric population}

Only three clinical trials regarding pediatric patients were included in this review. In children, serum anti-PLA2R antibody and renal PLA2R antigen positivity is less frequent than in adult PMN patients. Adolescent patients with PMN, however, seem to exhibit similar rates of PLA2R+ staining to those found in adults. ${ }^{61-63}$

\section{Anti-PLA2R antibodies and non-invasive PMN diagnosis}

Bobart et al. reviewed the potential of anti-PLA2R testing for non-invasive diagnosis of PMN. In this study, anti-PLA2R quantification was prompted in most cases due to the presence of nephrotic range proteinuria or nephrotic syndrome. 143 patients tested positively. Of these, 132 were subjected to kidney biopsy (KB) that confirmed MN diagnosis. After exclusion of secondary causes, KB provided little or no management-altering information. ${ }^{15}$

\section{DISCUSSION}

This systematic review shows the persistently increasing value of PLA2R studies in MN patients, particularly when it comes to diagnosis and disease management. Despite our expanding grasp of the significance of anti-PLA2R antibodies, several areas still require further investigation.

One of these relates to ELISA cut-off values. As previously mentioned, reported sensitivity for anti-PLA2R ELISA testing had significant interstudy variability (44.1 to $88.9 \%$ ). Reducing the threshold for positivity might push results higher up the sensitivity spectrum with no prejudice to test specificity as suggested by Tampoia et al. ${ }^{33}$. Further studies are required to validate these findings, but if results are consistent, the recommended cut-off value should be significantly reduced.

In recent years, several studies have confirmed that different immunoglobulin IgG subtypes relate to distinct $M N$ etiologies - IgG4 is predominant in $P M N$, while IgG1 and IgG3 occur mainly in SMN. ${ }^{27,34,58,64,65}$ Yang et al. suggest anti-PLA2R IgG4 monitoring might constitute a more effective technique than total antibody quantification. ${ }^{35}$ Further research is necessary to better understand immunological interactions in PMN patients and to determine how IgG characterization would be better applied in our clinical practice.

As previously mentioned, anti-PLA2R baseline quantification in transplant recipients is of uncertain value. Of the three included articles on this topic, two dismiss a correlation between antibody titers at the time of transplantation and risk of disease recurrence. ${ }^{23,59}$ The third suggests titers above $29 \mathrm{RU} / \mathrm{mL}$ are highly sensitive and specific predictive markers of disease relapse. ${ }^{60}$ Seitz-Polski et al. suggest however that persistently positive anti-PLA2R activity six months after kidney transplant is significantly associated with MN recurrence. ${ }^{59}$ As such, PLA2R antibody testing should be considered prior to kidney transplantation in patients with history of PMN. Patients with significant PLA2R titers should be monitored closely post-transplant for proteinuria and graft disfunction. Repeated testing should be considered to document persistent PLA2R activity, when possible. Both Seitz-Polski and Gupta et al. suggest the use of stronger immunosuppressive regimens might constitute a protective factor for disease recurrence. ${ }^{59,60}$ Preemptive rituximab therapy is another potential strategy. ${ }^{60}$ Prospective studies with larger samples are needed to validate these findings and confirm the legitimacy of these approaches.

PLA2R studies are also of dubious value in children. Again, only three clinical trials regarding this population were included in this review. All showed serum anti-PLA2R antibody and renal PLA2R antigen positivity to be less frequent than in adult PMN patients, which suggests a different underlying etiology. Further studies are required in this area, preferably with greater and more ethnically diverse samples to avoid potential confounding factors. ${ }^{61-63}$

The identification of PLA2R's immunodominant epitope (a protein complex consisting of cysteine-rich, fibronectin-like type II, and C-type lectin-like domains) was an important breakthrough in this biomarker's relatively short lifespan. ${ }^{66}$ Seitz-Polski et al. state that epitope spreading at baseline is an independent risk factor for non-remission and should be included in the therapeutic decision, depending on further confirmatory studies. ${ }^{67}$

To conclude, despite KB still being considered the gold standard for MN diagnosis, a noninvasive approach through anti-PLA2R antibody quantification is an increasingly pertinent alternative. Considering the high positive predictive value of anti-PLA2R testing for tissue diagnosis of PMN, KB may soon be considered a superfluous and invasive procedure in patients with stable renal function. ${ }^{15}$ Sidelining KB in the diagnostic approach could imply a revision of the nomenclature associated with this disease, as a membranous histopathologic presentation would no longer be the hallmark feature of MN. However, most authors support a continued role for $\mathrm{KB}$ in patients presenting with severe azotemia, in spite of PLA2R positivity. Figure 2 shows a potential algorithm for noninvasive $\mathrm{MN}$ diagnosis applying current knowledge on PLA2R-associated biomarkers.

\section{CONCLUSION}

Anti-PLA2R antibody positivity in the context of nephrotic syndrome is very suggestive of MN. Despite occurring more frequently in primary 


\section{Figure 2}

Proposed non-invasive diagnostic algorithm, based on Bobart et al.

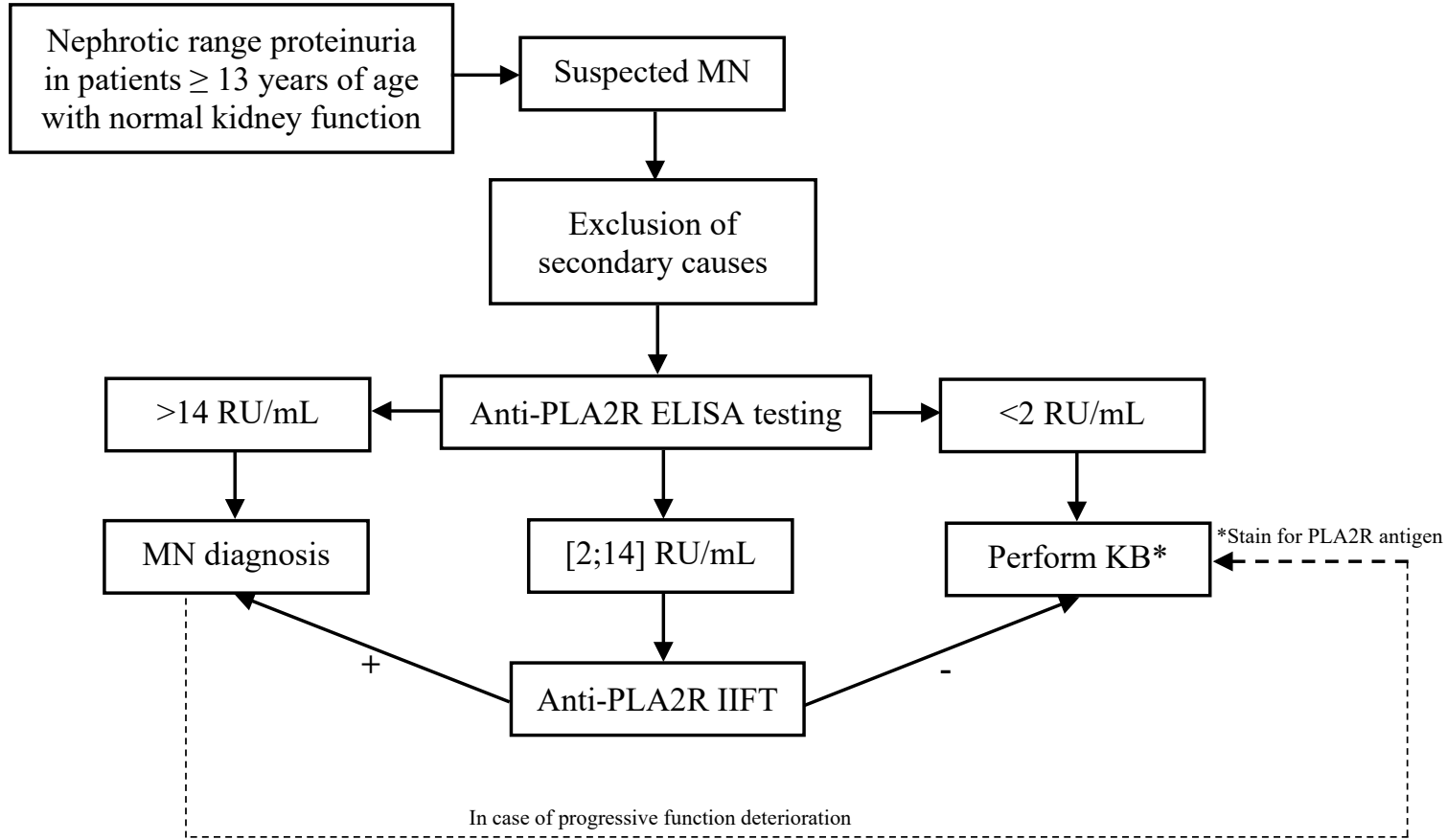

forms, exclusion of neoplasia and autoimmune disorders is still indispensable, as anti-PLA2R may also be present in secondary cases.

This biomarker is assuming an increasingly important role in the assessment of PMN activity, risk of recurrence and therapeutic monitoring. However, its interpretation must always be integrated with other markers of renal function. Immunoglobulin subtype characterization and PLA2R antigen staining can be useful to further characterize MN patients. IgG4 predominance supports PMN diagnosis, while dual positivity for PLA2R antigen deposits and anti-PLA2R antibodies might indicate increased disease severity and serve as supportive evidence for more aggressive therapeutic measures.

In the future, to increase this marker's clinical applicability, standardized cut-off values for seropositivity and for risk stratification must be set, taking into account the different detection methods used.

\section{Disclosure of potential conflicts of interest: none declared}

\section{References}

1. Ponticelli C. Membranous nephropathy. J Nephrol. 2007;20(3):268-87.

2. Ronco $\mathrm{P}$, Ronco $\mathrm{P}$, Debiec H. Pathogenesis of membranous nephropathy: recent advances and future challenges. Nat Rev Nephrol. 2012;8(4):203-213.

3. Barrett C, Willcocks LC, Jones RB, Tarzi RM, Henderson RB, Cai G, et al. Effect of belimumab on proteinuria and anti-phospholipase A2 receptor autoantibody in primary membranous nephropathy. Nephrol Dial Transplant. 2019;1-8.

4. Cattran D. Management of membranous nephropathy: When and what for treatment. J Am Soc Nephrol. 2005;16(5):1188-94.

5. Couser WG. Primary membranous nephropathy. Clin J Am Soc Nephrol. 2017;12(6):983-997.

6. Glassock RJ. The Pathogenesis of Idiopathic Membranous Nephropathy: A 50-Year Odyssey. Am J Kidney Dis. 2010;56(1):157-67.

7. Heymann W, Hackel DB, Harwood S, Wilson SGF, Hunter JLP. Production of Nephrotic Syndrome in Rats by Freund's Adjuvants and Rat Kidney Suspensions. Exp Biol Med. 1959;100(4):660-4.
8. Couser WG, Steinmuller DR, Stilmant MM, Salant DJ, Lowenstein LM. Experimental glomerulonephritis in the isolated perfused rat kidney. J Clin Invest. 1978;62(6):1275-1287.

9. Fleuren GJ, vd Lee R, Greben HA, Van Damme BJ, Hoedemaeker PJ. Experimental glomerulonephritis in the rat induced by antibodies directed against tubular antigens. IV. Investigations into the pathogenesis of the model. Lab Invest. 1978;38(4):496-501.

10. Couser WG, Salant DJ. In situ immune complex formation and glomerular injury. Kidney Int. 1980;17(1):1-13.

11. Kerjaschki D. Immunocytochemical localization of the Heymann nephritis antigen (GP330) in glomerular epithelial cells of normal Lewis rats. J Exp Med. 1983;157(2):667-86.

12. Debiec H, Guigonis V, Mougenot B, Decobert F, et al. Antenatal glomerulonephritis due to anti-neutral endopeptidase antibodies: Clinical heterogeneity within a family. N Engl J Med. 2002;346:2053-2060.

13. Debiec H, Nauta J, Coulet F, Van Der Burg M, Guigonis V, Schurmans T, et al. Role of truncating mutations in MME gene in fetomaternal alloimmunisation and antenatal glomerulopathies. Lancet. 2004:364(9441):1252-9.

14. Beck LH, Bonegio RGB, Lambeau G, Beck DM, Powell DW, Cummins TD, et al. M-type phospholipase A2 receptor as target antigen in idiopathic membranous nephropathy. N Engl J Med. 2009;361(1):11-21

15. Bobart SA, De Vriese AS, Pawar AS, Zand L, Sethi S, Giesen C, et al. Noninvasive diagnosis of primary membranous nephropathy using phospholipase A2 receptor antibodies. Kidney Int. 2019;95(2):429-38.

16. Herwig J, Skuza S, Sachs W, Sachs M, Failla AV, Rune G, et al. Thrombospondin type 1 domaincontaining 7A localizes to the slit diaphragm and stabilizes membrane dynamics of fully differentiated podocytes. J Am Soc Nephrol. 2019;30(5):824-39.

17. Ahmad SB, Appel GB. Antigens, antibodies, and membranous nephropathy: a decade of progress. Kidney Int. 2020;97(1):29-31.

18. Sethi S, Madden BJ, Debiec H, Cristine Charlesworth M, Gross L, Ravindran A, et al. Exostosin $1 /$ exostosin 2-associated membranous nephropathy. J Am Soc Nephrol. 2019;30(6):1123-36.

19. Sethi S, Debiec H, Madden B, Charlesworth MC, Morelle J, Gross LA, et al. Neural epidermal growth factor-like 1 protein (NELL-1) associated membranous nephropathy. Kidney Int. 2020;97(1):16374.

20. Hofstra JM, Beck Jr. LH, Beck DM, Wetzels JF, Salant DJ. Anti-phospholipase A2 receptor antibodies correlate with clinical status in idiopathic membranous nephropathy. ClinJAmSocNephrol. 2011;6(6):1286-91.

21. Hoxha E, Harendza S, Zahner G, Panzer U, Steinmetz O, Fechner K, et al. An immunofluorescence test for phospholipase-A2-receptor antibodies and its clinical usefulness in patients with membranous glomerulonephritis. Nephrol Dial Transplant. 2011;26(8):2526-32.

22. Beck LH, Fervenza FC, Beck DM, Bonegio RGB, Malik FA, Erickson SB, et al. Rituximab-Induced Depletion of Anti-PLA2R Autoantibodies Predicts Response in Membranous Nephropathy. J Am Soc Nephrol. 2011;22(8):1543-50. 
23. Debiec H, Martin L, Jouanneau C, Dautin G, Mesnard L, Rondeau E, et al. Autoantibodies specific for the phospholipase A 2 receptor in recurrent and de novo membranous nephropathy. Am J Transplant. 2011;11(10):2144-52.

24. Stahl R, Hoxha E, Fechner K. PLA2R Autoantibodies and Recurrent Membranous Nephropathy after Transplantation. N Engl J Med. 2010;363(5):496-8.

25. Larsen CP, Walker PD. Phospholipase A2 receptor (PLA2R) staining is useful in the determination of de novo versus recurrent membranous glomerulopathy. Transplantation. 2013;95(10):1259-62.

26. Kim YSYG, Choi Y-W, Kim S-Y, Moon JY, Ihm C-G, Lee TW, et al. Anti-phospholipase A2 receptor antibody as prognostic indicator in idiopathic membranous nephropathy. Am J Nephrol. 2015;42(3):250-7.

27. Liu L, Chang B, Wu X, Guo Y, Pan Y, Yang L. Expression of phospholipase a2 receptor and IgG4 in patients with membranous nephropathy. Vasc Health Risk Manag. 2018;14:103-8.

28. Zhang Q, Huang B, Liu X, Liu B, Zhang Y, Zhang Z, et al. Ultrasensitive Quantitation of Anti-Phospholipase A2 Receptor Antibody as A Diagnostic and Prognostic Indicator of Idiopathic Membranous Nephropathy. Sci Rep. 2017;7(1).

29. Lin W, Li H, Li X, Qin Y, Su Y, Yu Y, et al. [The relationship between anti-phospholipase A2 receptor antibody and idiopathic membranous nephropathy]. Zhonghua nei ke za zhi. 2015;54(9):783-8.

30. Qin W, Beck Jr. LH, Zeng C, Chen Z, Li S, Zuo K, et al. Anti-phospholipase A2 receptor antibody in membranous nephropathy. J Am Soc Nephrol. 2011;22(6):1137-43.

31. Radice A, Pieruzzi F, Trezzi B, Ghiggeri G, Napodano P, D'Amico M, et al. Diagnostic specificity of autoantibodies to M-type phospholipase A2 receptor (PLA2R) in differentiating idiopathic membranous nephropathy (IMN) from secondary forms and other glomerular diseases. J Nephrol. 2018;31(2):271-8.

32. Dou Y, Zhang L, Liu D, Wang C, Quan S, Ma S, et al. The accuracy of the anti-phospholipase A2 receptor antibody in the diagnosis of idiopathic membranous nephropathy: a comparison of different cutoff values as measured by the ELISA method. Int Urol Nephrol. 2016;48(6):845-9.

33. Tampoia M, Migliucci F, Villani C, Abbracciavento L, Rossini M, Fumarulo R, et al. Definition of new cut-off for the anti-phospholipase A2 receptor (PLA2R) autoantibody immunoassay in patients affected by idiopathic membranous nephropathy. J Nephrol. 2018;31(6):899-905.

34. Hihara K, lyoda M, Tachibana S, Iseri K, Saito T, Yamamoto Y, et al. Anti-phospholipase A2 receptor (PLA2R) antibody and glomerular PLA2R expression in Japanese patients with membranous nephropathy. PLoS One. 2016;11(6).

35. Yang $Y$, Wang C, Jin L, He F, Li C, Gao Q, et al. IgG4 anti-phospholipase A2 receptor might activate lectin and alternative complement pathway meanwhile in idiopathic membranous nephropathy: an inspiration from a cross-sectional study. Immunol Res. 2016;64(4):919-30.

36. Hoxha E, Harendza S, Pinnschmidt HO, Tomas NM, Helmchen U, Panzer U, et al. Spontaneous remission of proteinuria is a frequent event in phospholipase A2 receptor antibody-negative patients with membranous nephropathy. Nephrol Dial Transplant. 2015;30(11):1862-9.

37. Wang Y, Su M-L, Zheng A-P, Li M-H, Liang W, Xiong Z-Y. Anti-M-type phospholipase A2 receptor antibody diagnosing and monitoring disease activity in idiopathic membranous nephropathy: A single center and retrospective cohort study. Int J Clin Exp Med. 2016;9(12):23351-62.

38. Song EJ, Jeong KH, Yang YA, Lim J-H, Jung H-Y, Choi J-Y, et al. Anti-phospholipase A2 receptor antibody as a prognostic marker in patients with primary membranous nephropathy. Kidney Res Clin Pract. 2018:37(3):248-56.

39. Oh YJ, Yang SH, Kim DK, Kang S-W, Kim YS. Autoantibodies against phospholipase A2 receptor in Korean patients with membranous nephropathy. PLoS One. 2013;8(4):e62151.

40. Gopalakrishnan N, Abeesh P, Dineshkumar T, Murugananth S, Sakthirajan R, Raman GS, et al. Prevalence of serum anti M-type phospholipase A2 receptor antibody in primary membranous nephropathy: A single center experience. Indian J Nephrol. 2016;26(4):257-61.

41. Wu X, Wen S, Zhu X, Yuan S, Xu X, Yang D, et al. [Diagnostic value of renal phospholipase A2 receptor and serum anti-phospholipase $A 2$ receptor antibody in membranous nephropathy]. Zhong Nan Da Xue Xue Bao Yi Xue Ban. 2017;42(4):395-9.

42. Radice A, Trezzi B, Maggiore U, Pregnolato F, Stellato T, Napodano P, et al. Clinical usefulness of autoantibodies to M-type phospholipase A2 receptor (PLA2R) for monitoring disease activity in idiopathic membranous nephropathy (IMN). Autoimmun Rev. 2016;15(2):146-54.

43. Hoxha E, Harendza S, Pinnschmidt H, Panzer U, Stahl RAK. M-type phospholipase A2 receptor autoantibodies and renal function in patients with primary membranous nephropathy. Clin J Am Soc Nephrol. 2014:9(11):1883-90.

44. Yachha M, Sharma RK, Mehrotra S, Prasad N, Gupta A, Kaul A, et al. Anti-phospholipase A2 recep tor antibody in membranous nephropathy; an Indian experience. J Ren Inj Prev. 2018;7(1):16-21.

45. Hoxha E, Kneiler U, Stege G, Zahner G, Thiele I, Panzer U, et al. Enhanced expression of the M-type phospholipase A2 receptor in glomeruli correlates with serum receptor antibodies in primary membranous nephropathy. Kidney Int. 2012;82(7):797-804.

46. Qin H-Z, Zhang M-C, Le W-B, Ren Q, Chen D-C, Zeng C-H, et al. Combined assessment of phospholipase A2 receptor autoantibodies and glomerular deposits in membranous nephropathy. Am Soc Nephrol. 2016;27(10):3195-203.

47. Hoxha E, Thiele I, Zahner G, Panzer U, Harendza S, Stahl RAK. Phospholipase A2 receptor autoantibodies and clinical outcome in patients with primary membranous nephropathy. J Am Soc Nephrol. 2014;25(6):1357-66.

48. Akiyama S., Akiyama M, Imai E, Ozaki T, Matsuo S, Maruyama S. Prevalence of anti-phospholipase A2 receptor antibodies in Japanese patients with membranous nephropathy. Clin Exp Nephrol. 2015;19(4):653-60.

49. Jatem Escalante E, Segarra Medrano A, Carnicer Cáceres C, Martín-Gómez MA, Salcedo Allende MT, Ostos Roldan $\mathrm{H}$, et al. Clinical features, course and prognosis of idiopathic membranous nephropathy depending on the presence of antibodies against $\mathrm{M}$-type phospholipase $\mathrm{A} 2$ receptor. Nefrologia. 2015;35(5):479-86.

50. Jullien P, Polski BS, Maillard N, Thibaudin D, Laurent B, Ollier E, et al. Anti-phospholipase A2 receptor antibody levels at diagnosis predicts spontaneous remission of idiopathic membranous nephropathy. Clin Kidney J. 2017;10(2):209-14.

51. Ruggenenti P, Debiec H, Ruggiero B, Chianca A, Pellé T, Gaspari F, et al. Anti-Phospholipase A2 receptor antibody titer predicts post-rituximab outcome of membranous nephropathy. J Am Soc Nephrol. 2015;26(10):2545-58.
52. Qu Z, Zhang MF, Cui Z, Wang J, Wang M, Zhang YM, et al. Antibodies against M-type phospholipase A2 receptor may predict treatment response and outcome in membranous nephropathy. Am J. Nephrol. 2018;48(6):438-46.

53. Medrano AS, Escalante EJ, Cáceres CC, Pamplona IA, Allende MTS, Terrades NR, et al. Prognostic value of the dynamics of $\mathrm{M}$-type phospholipase $\mathrm{A} 2$ receptor antibody titers in patients with idiopathic membranous nephropathy treated with two different immunosuppression regimens. Biomarkers. 2015;20(1):77-83.

54. Segarra-Medrano A, Jatem-Escalante E, Carnicer-Caceres C, Agraz-Pamplona I, Salcedo MT, Valtierra N, et al. Evolution of antibody titre against the M-type phospholipase $\mathrm{A} 2$ receptor and clinical response in idiopathic membranous nephropathy patients treated with tacrolimus. Nefrologia. 2014:34(4):491-7.

55. Xu NX, Xie $\mathrm{OH}$, Sun ZX, Wang J, Li Y, Wang L, et al. Renal phospholipase A2 receptor and the clinical features of idiopathic membranous nephropathy. Chin Med J (Engl). 2017;130(8):892-8.

56. Roy S, Korula A, Basu G, Jacob S, Varughese S, Tamilarasi V. Immunohistochemical Glomerular Expression of Phospholipase A2 Receptor in Primary and Secondary Membranous Nephropathy: A Retrospective Study in an Indian Cohort with Clinicopathological Correlations. Nephron Extra. 2017;7(1):1-9.

57. Li YQ, Liu ZZ, Lin KX, Liu RH, Ni L, Liu GX, et al. Relationship between the status of phospholipase A2 receptor and prognosis of idiopathic membranous nephropathy. Nephrology. 2020;25(2):144-149.

58. Hayashi N, Akiyama S, Okuyama H, Matsui Y, Adachi H, Yamaya H, et al. Clinicopathological characteristics of M-type phospholipase A2 receptor (PLA2R)-related membranous nephropathy in Japanese. Clin Exp Nephrol. 2015;19(5):797-803.

59. Seitz-Polski B, Payré C, Ambrosetti D, Albano L, Cassuto-Viguier E, Berguignat M, et al. Prediction of membranous nephropathy recurrence after transplantation by monitoring of anti-PLA2R1 (M-type phospholipase A2 receptor) autoantibodies: A case series of 15 patients. Nephrol Dial Transplant. 2014;29(12):2334-42.

60. Gupta G, Fattah H, Ayalon R, Kidd J, Gehr T, Quintana LF, et al. Pre-transplant phospholipase A2 receptor autoantibody concentration is associated with clinically significant recurrence of membranous nephropathy post-kidney transplantation. Clin Transplant. 2016;30(4):461-9.

61. Kanda S, Horita S, Yanagihara T, Shimizu A, Hattori M. M-type phospholipase A2 receptor (PLA2R) glomerular staining in pediatric idiopathic membranous nephropathy. Pediatr Nephrol. 2017 Apr;32(4):713-7.

62. Kumar V, Ramachandran R, Kumar A, Nada R, Suri D, Gupta A, et al. Antibodies to m-type phospholipase A2 receptor in children with idiopathic membranous nephropathy. Nephrology. 2015;20(8):572-5

63. Zhang D, Wu Y, Zhang C, Zhang W, Zou J, Jiang G. Compared staining of the phospholipase A2 receptor in the glomeruli of Chinese adults and children with idiopathic membranous nephropathy. Pathol Res Pract. 2019;215(5):952-6.

64. Yeo M-K, Kim YH, Choi DE, Choi S-Y, Kim K-H, Suh K-S. The Usefulness of Phospholipase A2 Receptor and IgG4 Detection in Differentiation Primary Membranous Nephropathy From Secondary Membranous Nephropathy in Renal Biopsy. Appl Immunohistochem Mol Morphol AIMM. 2018;26(8):591-8.

65. Liu H, Luo W, Gong S, Ding X. Detection and clinical significance of glomerular M-type phospholipase A2 receptor in patients with idiopathic membranous nephropathy. Intern Med J. 2016;46(11):1318-22.

66. Kao L, Lam V, Waldman M, Glassock RJ, Zhu Q. Identification of the immunodominant epitope region in phospholipase $\mathrm{A} 2$ receptor-mediating autoantibody binding in idiopathic membranous nephropathy. J Am Soc Nephrol. 2015;26(2):291-301.

67. Seitz-Polski B, Debiec H, Rousseau A, Dahan K, Zaghrini C, Payré C, et al. Phospholipase A2 Receptor 1 Epitope Spreading at Baseline Predicts Reduced Likelihood of Remission of Membranous Nephropathy. J Am Soc Nephrol. 2018;29(2):401-8.

68. Ardalan MR, Ghafari A, Hamzavi F, Nasri H, Baradaran B, Majidi J, et al. Anti-phospholipase A2 receptor antibody in idiopathic membranous nephropathy: A report from Iranian population. J Nephropathol. 2013;2(4):241-8.

69. Segarra-Medrano A, Jatem-Escalante E, Quiles-Perez MT, Salcedo MT, Arbos-Via MA, Ostos H, et al. Prevalence, diagnostic value and clinical characteristics associated with the presence of circulating levels and renal deposits of antibodies against the M-type phospholipase A2 receptor in idiopathic membranous nephropathy. Nefrologia. 2014;34(3):353-9.

70. Kimura Y, Miura N, Debiec H, Morita H, Yamada H, Banno S, et al. Circulating antibodies to alpha-enolase and phospholipase A2 receptor and composition of glomerular deposits in Japanese patients with primary or secondary membranous nephropathy. Clin Exp Nephrol. 2017;21(1):117-26.

71. Cheng G, Liu J, Gilbert A, Cao Y, An C, Lv Z, et al. Serum phospholipase A2 receptor antibodies and immunoglobulin $\mathrm{G}$ subtypes in adult idiopathic membranous nephropathy: Clinical value assessment. Clin Chim Acta. 2019;490:135-41.

72. Chi JN, Lai TS, Wu CF, Fu TY, Chou YH, Chiu YL, et al. The relationship of anti-phospholipase A2 receptor antibody and C5a complement with disease activity and short-term outcome in idiopathic membranous nephropathy. J Formos Med Assoc. 2019;118(5):898-906.

73. Provatopoulou S, Kalavrizioti D, Stangou M, Kouri MN, Kalliakmani P, Papasotiriou M, et al. Circulating anti-phospholipase A2 receptor antibodies as a diagnostic and prognostic marker in Greek patients with idiopathic membranous nephropathy - a retrospective cohort study. Rom J Intern Med. 2019;57(2):141-50.

74. Fervenza FC, Appel GB, Barbour SJ, Rovin BH, Lafayette RA, Aslam N, et al. Rituximab or cyclosporine in the treatment of membranous nephropathy. N Engl J Med. 2019;381(1):36-46

\section{Correspondence to:}

Miguel Relvas, MD

Nephrology Department, Centro Hospitalar e Universitário de São João,

Oporto, Portugal

Email: mic21892@gmail.com 